\title{
MODERNISASI PRODUKSI GULA AREN DI DESA TONGO KECAMATAN SEKONGKANG KABUPATEN SUMBAWA BARAT
}

\author{
Agus ${ }^{1}$, Muhammad Saleh ${ }^{2 *}$, Harjito ${ }^{3^{*}}$ \\ 1,2Sekolah Pascasarjana Universitas Teknologi Sumbawa \\ ${ }^{3}$ Fakultas Teknologi Pertanian Universitas Teknologi Sumbawa \\ "Corresponding Autor Email: muhammad.saleh@uts.ac.id, harjito@uts.ac.id
}

\begin{abstract}
Abstrak
Penelitian ini bertujuan untuk merumuskan alternatif strategi yang harus diterapkan

Diterima :

Bulan Juni

2020

Diterbitkan:

Bulan Juli

2020

Keyword :

Modernisasi,

gula aren, Analisis

SWOT dan Strategi

Pengembangan

dalam pengembangan produksi gula aren melalui modernisasi untuk meningkatkan kualitas dan kuantitas produk sehingga berdampak langsung terhadap peningkatan kesejahteraan masyarakat desa khususnya pengrajin gula aren. Lokasi penelitian dilaksanakan di Dusun Sejorong Desa Tongo, Kecamatan Sekongkang Kabupaten Sumbawa Barat. Waktu penelitian dilaksanakan pada bulan November 2019 dan Pebruari 2020. Jenis penelitian yang digunakan dalam penelitian ini adalah metode survey langsung. Data yang dikumpulkan bersumber dari data primer dan data sekunder. Data primer dilakukan dengan cara observasi lapangan, dokumentasi dan wawancara dengan perajin gula aren dengan menggunakan daftar pertanyaan (Question). Data sekunder diperoleh dari berbagai instansi-instansi terkait dan informasi dari berbagai literatur yang berhubungan dengan penelitian ini. Populasi dalam penelitian ini adalah pengrajin tradisional gula aren yang berjumlah 4 orang dan pengrajin kelompok Jalit L estari Desa tongo. Sampel dalam penelitian ini diambil dengan cara purpose sampling yaitu penentuan sampel dengan tujuan tertentu. Teknik analisa data menggunakan analisis deskriptif untuk mengetahui tentang modernisasi produksi gula aren di Desa Tongo dan Analisis alternatif strategi dengan menggunakan analisis SWOT digunakan untuk menentukan strategi pengembangannya. Hasil penelitian menunjukkan bahwa berdasarkan analisis internal dan ekternal, industri kecil gula Aren di Desa Tongo Kecamatan sekongkang ini memiliki kekuatan yang dapat dipertahankan atau ditingkatkan, serta memiliki peluang yang bisa dimanfaatkan dengan baik dan semaksimal mungkin. Strategi pengembangan yang sebaiknya digunakan adalah strategi yang mendukung pertumbuhan agresif.
\end{abstract}

\section{PENDAHULUAN}

Pembangunan pertanian pada era globalisasi diharapkan pada tuntutan peningkatan produktifitas dan efisiensi agar dapat bersaing di pasar domestik maupun global. Sasaran pembangunan pertanian diarahkan kepada peningkatan pendapatan dan kesejahteraan petani melalui pemberdayaan masyarakat tani. Dalam pencapaian sasaran pembangunan tersebut, maka kebijakan dan strategi pembangunan pertanian dilakukan melalui pengembangan dan sistem dan usaha secara utuh dan terpadu.

Sebagai penggerak pembangunan pertanian, industri diharapkan dapat memainkan peranan penting kegiatan pembangunan daerah dalam sasaran pemerataan pembangunan ekonomi. Keberadaan industri di perdesaan diharapkan dapat meningkatkan permintaan terhadap komoditas pertanian, karena agroindustri berperan dalam mengubah produk pertanian menjadi barang yang berguna bagi kebutuhan masyarakat (Feryanto, 2010).

Salah satu hasil pertanian yang dapat gunakan dalam industri pengolahan adalah dari tanaman Aren. Aren merupakan tumbuhan multiguna memberikan banyak manfaat bagi kehidupan masyarakat. Pohon penghasil cairan manis ini memiliki fungsi dan peran penting secara ekologis, ekonomi, sosial dan budaya masyarakat Indonesia, khususnya perajin pedesaan (Apandi, 2008) Tanaman aren dapat menghasilkan nira 
aren yang diolah menjadi Gula aren. Namun dalam penanganan proses pengolahannya masih sangat terbatas dan umumnya dikerjakan secara tradisional.

Industri gula aren di desa Tongo sebagian besar dikelola secara individu dengan teknologi yang diwariskan secara turun temurun (konvensional) dan sebagian kecil dikelola secara kelompok dengan menggunakan mesin ekstraksi bantuan dari PT AMNT. Selama ini pengrajin gula aren rumahan hanya memanfaatkan nira aren untuk diolah menjadi gula aren cetak (berbentuk padat) dan hanya mampu menghasilkan 8- $18 \mathrm{~kg}$ gula perhari karena terbatasnya sumber daya manusia dan alat yang sederhana sedangkan pengrajin kelompok Jalit Lestari yang memanfaatkan nira aren atau gula aren yang sudah jadi dari pembuat gula aren lokal desa Tongo menjadi produk lain seperti gula semut, produksi gula yang di hasilkan bisa meningkat menjadi lima kali lipat.

Masalah yang terjadi pada pembuatan gula aren cetak yang dilakukan oleh pengrajin rumahan di desa Tongo diantaranya adalah sumber daya manusia, wadah pembuatan yang terlalu kecil sehingga terjadi penggosongan yang disebabkan oleh tidak terkontrolnya suhu pada saat pemasakan karena pemasakan nira masih menggunakan kayu serta pengrajin harus berkotor-kotor dengan jelaga dan menahan panas dari pembakaran kayu, nira yang dituangkan kedalam cetakan-cetakan berbahan bambu yang sebenarnya kurang higienis karena bambu mengeluarkan bubuk putih yang bisa membuat gula menjadi kotor. Selain itu kandungan air yang terdapat pada gula aren cetak masih tinggi. Faktor yang mempengaruhi kandungan air pada gula aren cetak yang dihasilkan adalah suhu pemasakan yang terlalu rendah dan proses kristalisasi yang kurang sempurna. Gula aren cetak jika disimpan pada suhu kamar dengan kondisi pengemasan yang kurang baik akan mengakibatkan mudah mencair. Keadaan ini dapat mengakibatkan kerugian bagi pedagang-pedagang.

Untuk mengatasi permasalahan tersebut diperlukan modernisasi dalam memproduksi gula aren yang berkualitas dan yang lebih efisien dengan mengembangkan pengolahan gula aren menjadi gula semut yang dikemas modern. Bentuk akhir gula semut ini adalah serbuk, sehingga menjadikan gula semut ini lebih praktis untuk digunakan dan harga jual gula semut lebih tinggi (Ningtyas $d k k$., 2014).

Permintaan akan gula semut terus meningkat dari waktu ke waktu karena target pasar industri yang sangat mempertimbangkan efisiensi, dan mengutamakan sisi kepraktisan dibandingkan dengan menggunakan gula merah biasa. Saat ini gula semut yang di hasilkan oleh kelompok Jalit Lestari Desa Tongo telah banyak dipasarkan pada beberapa supermarket dan di toko-toko disekitar Kecamatan Maluk dan Jereweh. Selain itu, gula semut dapat tahan lama tanpa penambahan bahan pengawet (Ningtyas $d k k$., 2014).

Sebagai penghasil aren, posisi daya saing dari desa Tongo masih lemah dan perkembangan industri gula aren masih sulit berkembang terutama pada pengrajin rumahan. Hal tersebut, masih terhambat oleh berbagai tantangan dan permasalahan seperti rendahnya produktivitas, keterbatasan sumber daya manusia, modal, teknologi pengolahan yang masih bersifat tradisional lebih banyak dari pada yang yang modern, ruang lingkup pemasaran belum sampai keluar daerah, adanya persaingan dengan produk gula yang berasal dari tebu, serta adanya produk gula aren dari daerah lain.

Produksi gula aren mempunyai nilai penting dalam meningkatkan kesejahteraan masyarakat desa Tongo.Pengembangan industri gula aren banyak menghadapi kendala yang harus disikapi karena adanya faktor-faktor yang menghambat usaha industri tersebut, oleh karena itu diperlukan rumusan strategi dalam pengembangannya.Strategi pengembangan industri gula aren yang ditempuh harus disesuaikan dengan permasalahan yang ada.Strategi pengembangan akan berpengaruh dalam menjaga daya saing dan kemajuan usaha sehingga mampu memberikan kontribusi bagi perekonomian pengrajin gula aren.

Dengan demikian, tujuan dalam penelitian ini adalah untuk merumuskan alternatif strategi yang harus diterapkan dalam pengembangan industri gula aren melalui modernisasi untuk meningkatkan kualitas dan kuantitas produk sehingga berdampak langsung terhadap peningkatan kesejahteraan masyarakat desa khususnya pengrajin gula aren.

\section{LANDASAN TEORI}

\section{Modernisasi}

Modernisasi adalah: (1) teori ini didasarkan pada dikotomi modern tradisional. Yang modern merupakan simbol kemajuan, pemikiran rasional, metode kerja efisien, dan seterusnya. Masyarakat modern dianggap sebagai ciri masyarakat dinegaranegara industri maju.Sebaliknya masyarakat tradisional merupakan kebalikannya.(2) Teori modernisasi juga didasarkan pada faktor-faktor nonmaterial sebagai penyebab kemiskinan, khususnya dunia ide atau alam pikiran. Faktor-faktor ini kemudian menjelma kealam psikologi individu atau nilai-nilai kemasyarakatan yang menjadi orientasi penduduk dalam memberikan arah tingkah laku.(3) Teori 
modernisasi biasanya ahistoris. Hukum-hukumnya sering dianggap berlaku secara universal tanpa memperhatikan faktor waktu dan tempat. Contoh dari kasus ini adalah masalah rasionalitas, atau masalah efisensi, (Budiman, Assyaukanie, \& Stanley, 2006)

Jika modernisasi didefinisikan seperti diatas dan berlaku pada seluruh aspek kehidupan manusia, khususnya manusia Indonesia, proses modernisasi akan menjadi suatu kekuatan pembangunan yang besar. Tetapi yang terjadi sesungguhnya adalah diluar kemampuan bangsa Indonesia sehingga modernisasi di Indonesia didefinisikan sebagai Industrialisasi.

Persoalannya adalah apakah seluruh kelompok masyarakat telah siap menerima konsep modernisasi sesuai dengan teori yang sesungguhnya, ataukah hanya ada sebagian masyarakat saja. Bukti empirik dalam kasus ini tentu dapat kita lihat bahwa saat ini terjadi ketimpangan distribusi pendapatan yang cukup dashyat, dalam hal mana sebagian kelompok masyarakat (menengah atas) melambung tinggi akibat kemajuan dan perubahan sosial, sedangkan sebagian lagi tertinggal dibelakang, tenggelam dan jauh sekali dari kata 'makmur'.

\section{Produksi}

Perkembangan suatu industri erat dengan kebutuhan permintaan pasar. Permintaan pasar yang tinggi akan mendorong munculnya kegiatan suatu industri. Kegiatan industri pada dasarnya adalah kegiatan yang mengolah barang mentah menjadi barang jadi yang memiliki nilai guna yang lebih tinggi. Tujuan suatu industri dalam menghasilkan barang atau jasa, meningkatkan kemakmuran masyarakat, meningkatkan keuntungan, memperluas lapangan pekerjaan, dan menjaga kesinambungan usaha perusahaan.

Untuk menghasilkan barang atau jasa dalam kegiatan industri tentunya ada faktor yang menunjang proses produksi yang disebut faktor produksi seperti SDA, SDM, modal, teknologi dan masalah pemasaran. Faktor-faktor tersebut merupakan suatu bagian yang sangat penting, karena faktor-faktor tersebut yang akan menentukan keberlangsungan kegiatan industri tersebut. Alokasi faktor produksi dalam jumlah yang tepat akan memberikan pendapatan yang maksimal dan sebaliknya, penggunaan faktor produksi yang tidak tepat dapat menyebabkan ketidakefisienan yang dapat mengurangi keuntungan atau pendapatan.

\section{Gula Aren}

Gula aren merupakan salah satu olahan makanan yang bersumber dari hasil pengolahan air nira yang berasal dari tandan bunga jantan pohon aren. Pengolahan nira hingga menjadi gula aren melalui proses perebusan hinga nira berubah menjadi cairan kental dan berwarna pekat., kemudian dicetak dan didinginkan hingga mengeras (Balai Penelitian Tanaman Palma, 2010).

Gula merah cetak memiliki banyak kegunaan selain sebagai pemanis makanan juga digunakan sebagai penyedap masakan, campuran dalam pembuatan cuka untuk empek-empek, kecap dan lainlain.gula merah cetak dari nira aren memiliki aroma khas aren, warna coklat muda, rasa lebih manis dan bersih.

\section{Analisis SWOT}

Analisis SWOT adalah identifikasi berbagai faktor secara sistematis untuk merumuskan faktorfaktor pendorong dan penghambat pertumbuhan dan perkembangan sektor industri kecil gula aren.Analisis ini didasarkan pada logika yang dapat memaksimalkan kekuatan (strength) dan peluang (opportunities), namun secara bersamaan dapat meminimalkan kelemahan (weakness) dan ancaman (treats).(Rangkuti, 1998:19). Analisis SWOT membandingkan faktor eksternal peluang (opportunities) dan ancaman (treats) dengan faktor internal kekuatan (strength) dan kelemahan (weakness), untuk menghasilkan analisis yang tepat.

\section{Strategi Pengembangan}

Strategi adalah tujuan jangka panjang dari suatu perusahaan, serta pendayagunaan dan alokasi semua sumber daya yang penting untuk mencapai tujuan tersebut (Chandler, 1962:13 dalam Rangkuti, 2002:4). Pemahaman yang baik mengenai konsep strategi dan konsep-konsep lain yang bersangkutan sangat menentukan suksesnya strategi apa yang akan disusun.

Pengembangan adalah meningkatkan kualitasnya maupun kuantitasnya dalam suatu kegiatan (Irawan dan M. Suparmoko, 1992:6). Pengembangan juga berarti proses, cara, perbuatan mengembangkan.

strategi pengembangan usaha yaitu suatu rencana yang terpadu mengenai upaya-upaya suatu industri yang diperlukan guna mengembangkan usahanya dalam rangka mencapai tujuan secara efektif dan efisien. Untuk mencapai tujuan, industri harus memperhatikan sumber daya-sumber daya yang ada maupun keadaan lingkungan yang dihadapi. Sumber daya yang ada pada suatu industri yang berupa kekuatan maupun kelemahan, serta keadaan lingkungan dapat berupa peluang dan ancaman bagi industri itu sendiri. 


\section{METODOLOGI PENELITIAN}

Penelitian ini dilaksanakan di Dusun sejorong Desa Tongo, Kecamatan Sekongkang Kabupaten Sumbawa Barat.Penelitian dilaksanakan pada bulan November 2019 dan Pebruari 2020. Pengambilan sampel dilakukan dengan cara purpose sampling yaitu penentuan sampel dengan tujuan tertentu.terhadappengrajin industri gula aren sebagai populasi. Jumlah sampel yang diambil dalam penelitian ini adalah sebanyak 7 responden dari jumlah populasi.

Jenis data yang digunakan dalam penelitian ini berupa data sekunder dan data primer. Teknik pengumpulan data yang digunakan adalah teknik observasi langsung ke lokasi yaitu di desa Tongo Kecamatan Sekongkang dengan cara wawancara, dokumentasi, dan pemberian angket atau kuisioner.Untuk analisis data dilakukan analisis statistik deskriptif dan analisis SWOT.

\section{HASIL PENELITIAN DAN PEMBAHASAN}

Dalam wawancara dengan beberapa narasumber baik pengrajin gula aren maupun fasilitator pengembangan produksi gula aren, ternyata ada beberapa faktor produksi yang mempengaruhi jumlah produksi gula aren. Faktor-faktor yang mempengaruhi pengembangan produksi gula aren diidentifikasi dengan menyusun matriks internal dan eksternal.

\section{Deskripsi faktor Internal}

Evaluasi terhadap faktor internal dilakukan dengan mengidentifikasi faktor kekuatan dan kelemahan sebagai berikut:

1) Pengrajin gula aren di wilayah Desa Tongo ini memiliki keahlian dalam mengolah dan membuat produk gula aren yang di dapatkan secara turuntemurun.

2) Dari segi sumber daya manusia (SDM), para pengrajin gula aren ini tidak memiliki karyawan yang dikerjakan, melainkan di kerjakan sendiri oleh anggota keluarga. Tingkat pendidikan para pengrajin juga mayoritas tergolong rendah, yaitu lulusan SMA kebawah. Hal ini menyebabkan beberapa pengrajin kurang paham dan cenderung acuh mengenai kegiatan pemasaran yang menguntungkan.

3) Bahan baku pembuatan gula aren mudah di dapatkan dan proses pembuatan gula aren seluruhnya dikerjakan secara manual dan masih menggunakan peralatan yang sederhana.

4) Pohon aren di Desa Tongo ada yang milik sendiri pengrajin gula aren dan ada yang menggunakan lahan milik pemerintah (tumbuh liar di sepanjang sungai), sehingga pemanfaatan bahan baku bisa maksimal.

5) Jumlah gula Aren yang dihasilkan setiap harinya adalah sebanyak 3 sampai 17 kilogram. Namun pada kenyataannya, hasil yang diperoleh tersebut bersifat fluktuatif (naik-turun), kadang bisa lebih banyak dan bahkan bisa kurang, hal tersebut disesuaikan dengan banyak/sedikitnya nira aren yang diperoleh dari proses penyadapan.

6) Produk gula aren mempunyai karakteristik yang unik dan khas dari pada produk gula lainnya. Produk gula aren umumnya berwarna merah kecoklatan, mempunyai rasa manis yang murni dan mempunyai manfaat di bidang kesehatan dan kuliner.

7) Mayoritas pemasaran produk gula aren ini hanya dilakukan oleh pengepul atau tengkulak saja. Pengrajin gula aren sendiri tidak pernah melakukan promosi dan jarang terjun langsung ke pasar.

8) Pada saat memulai atau mendirikan industri gula Aren ini pengrajin tidak menggunakan modal yang cukup besar, karena bahan baku yang digunakan adalah pohon aren milik sendiri, perlatan yang digunakan seperti wajan masih memakai warisan yang diberikan oleh orang tua.

9) Pengembangan industri gula aren menjadi gula semut sendiri sampai saat ini sudah berjalan dengan pembentukan kelompok Jalit Lestari walaupun masih banyak pengrajin yang bertahan dengan cara tradisional.

\section{Deskripsi faktor Eksternal}

Faktor eksternal pada industri pembuatan gula aren di Desa Tongo :

1) Jumlah nira aren dan kualitas produk gula aren sangat dipengaruhi oleh cuaca atau musim yang sedang terjadi.

2) Peran pemerintah dalam kegiatan industri pembuatan gula aren ini sangat dibutuhkan, dukungan dan bantuan dari pemerintah akan membuat para pengrajin bisa lebih mantap mengembangkan kegiatan industrinya hingga bisa menjadikan produk gula aren menjadi yang unggul.

3) Pemanfaatan teknologi informasi seperti internet dan media sosial yang saat ini semakin berkembang diharapkan para pengrajin gula aren mampu meningkatkan peluang pengembangan usaha gula aren. 
4) Rendahnya minat, ketertarikan generasi penerus, serta sedikitnya kecenderungan tenaga kerja muda untuk terjun dalam industri pembuatan gula aren.

5) Belum ada budidaya atau penanaman pohon aren dan adanya produk gula campuran, yaitu produk gula aren yang proses pembuatannya dicampur dengan menggunakan gula pasir dan gula kelapa.

6) dukungan dan peran pemerintah sangat dibutuhkan untuk merealisasikan pengembangan pemasaran produk gula Aren ini melalui tempat wisata, hal tersebut dapat diwujudkan dengan diadakannya kerjasama antara Dinas Kebudayaan dan Pariwisata dengan Dinas Perindustrian Koperasi dan UMKM Kabupaten Sumbawa Barat.

\section{Alternatif Strategi Pengembangan dengan Matriks SWOT.}

Matriks ini dapat menggambarkan secara jelas bagaimana faktor eksternal (peluang dan ancaman) yang dihadapi industri kecil gula Aaen di Desa Tongo dapat disesuaikan dengan faktor internal (kekuatan dan kelemahan) yang dimilikinya.Perumusan alternatif strategi melalui matriks SWOT ini disajikan dalam tabel 4.1.

Tabel 4. 1. Formulasi Matriks Analsis SWOT

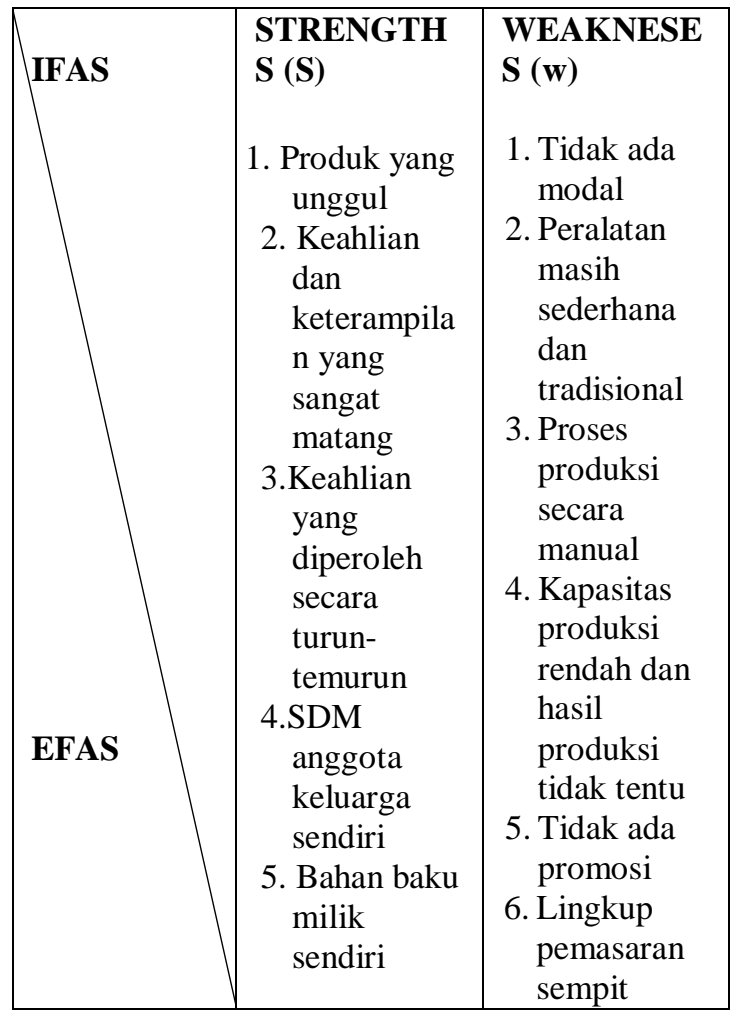

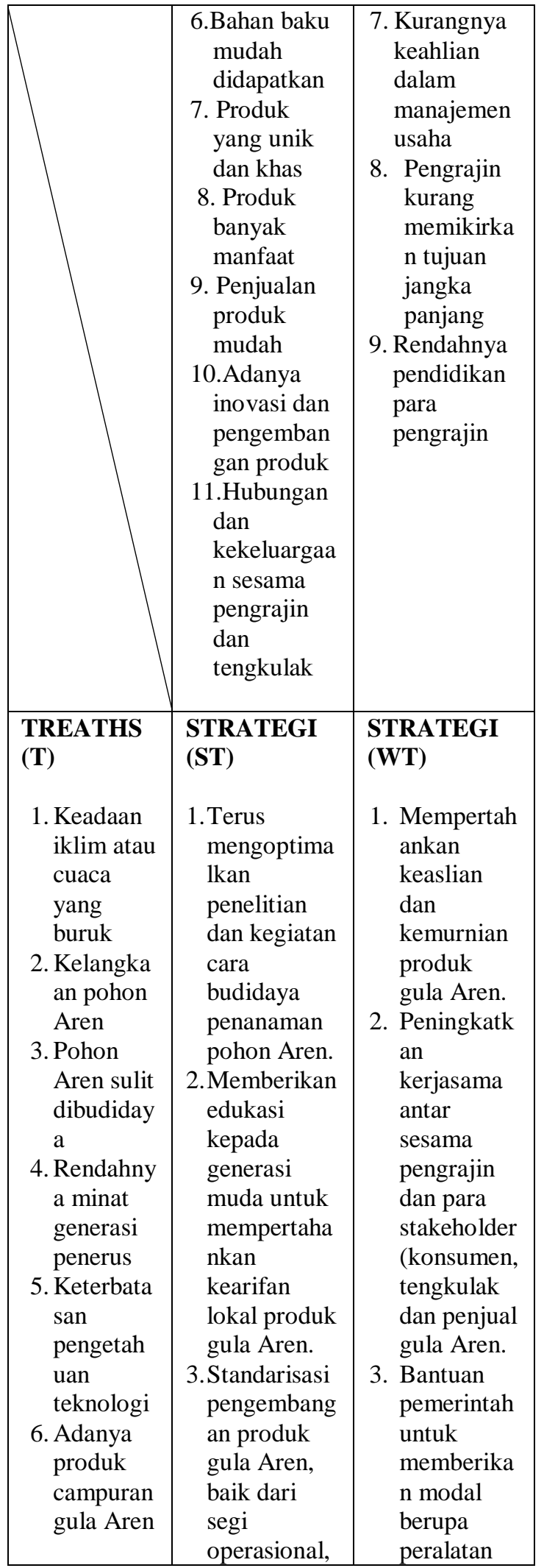




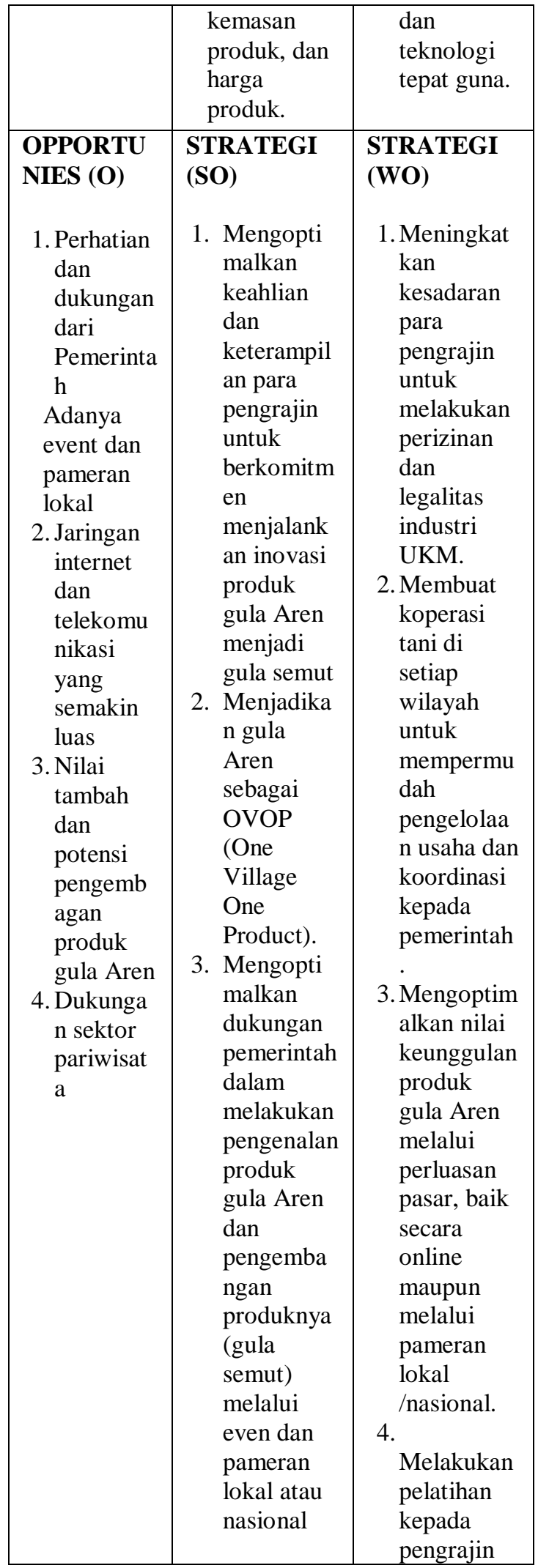

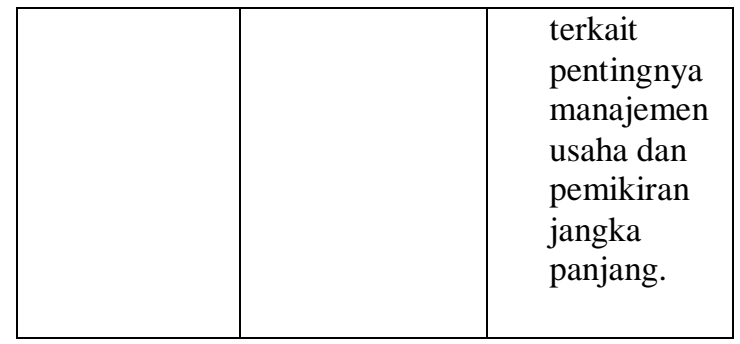

Penilaian Analisis SWOT

Proses perumusan strategi pengembangan industri kecil gula aren di Desa tongo ini dilakukan dengan menggunakan pendekatan kuantitatif Analisis SWOT. Semua faktor-faktor strategis baik internal (kekuatan dan kelemahan) maupun eksternal (peluang dan ancaman) dibuat menjadi kuesioner yang variabelnya diperoleh dari daftar faktor-faktor strategis tersebut.didapatkan hasil perhitungan yang ditampikan pada tabel berikut:

\section{Matriks Faktor Strategi Internal (Kekuatan dan Kelemahan)}

Tabel 4. 2. Matrik Faktor Strategi Internal (IFAS)

\begin{tabular}{|c|c|c|c|c|}
\hline \multicolumn{2}{|c|}{$\begin{array}{c}\text { Faktor-faktor Strategi } \\
\text { Internal } \\
\text { Kekuatan (Strenght) }\end{array}$} & Bobot & Rating & Skor \\
\hline S1 & $\begin{array}{l}\text { Produk yang } \\
\text { unggul }\end{array}$ & 0,060 & 3,428 & 0,205 \\
\hline S2 & $\begin{array}{l}\text { Keahlian dan } \\
\text { keterampilan } \\
\text { yang sangat } \\
\text { matang }\end{array}$ & 0,062 & 3,428 & 0,212 \\
\hline S3 & $\begin{array}{l}\text { Keahlian yang } \\
\text { diperoleh secara } \\
\text { turun-temurun }\end{array}$ & 0,062 & 3,285 & 0,203 \\
\hline S4 & $\begin{array}{l}\text { SDM anggota } \\
\text { keluarga sendiri }\end{array}$ & 0,058 & 3,000 & 0,174 \\
\hline S5 & $\begin{array}{l}\text { Bahan baku } \\
\text { milik sendiri }\end{array}$ & 0,056 & 3,857 & 0,215 \\
\hline S6 & $\begin{array}{l}\text { Bahan baku } \\
\text { mudah } \\
\text { didapatkan }\end{array}$ & 0,056 & 3,714 & 0,207 \\
\hline S7 & $\begin{array}{l}\text { Produk yang } \\
\text { unik dan khas }\end{array}$ & 0,071 & 3,714 & 0,263 \\
\hline S8 & $\begin{array}{l}\text { Penjualan } \\
\text { produk mudah }\end{array}$ & 0,054 & 3,571 & 0,192 \\
\hline S9 & $\begin{array}{l}\text { Produk banyak } \\
\text { manfaat }\end{array}$ & 0,060 & 4,000 & 0,24 \\
\hline
\end{tabular}




\begin{tabular}{|l|l|l|l|l|}
\hline S10 & $\begin{array}{l}\text { Adanya inovasi } \\
\text { dan } \\
\text { pengembangan } \\
\text { produk }\end{array}$ & 0,043 & 2,857 & 0,122 \\
\hline S11 & $\begin{array}{l}\text { Hubungan dan } \\
\text { kekeluargaan } \\
\text { sesama } \\
\text { pengrajin dan } \\
\text { tengkulak }\end{array}$ & 0,056 & 3,714 & 0,207 \\
\hline Total & & 0,638 & & 2,24 \\
\hline
\end{tabular}

\begin{tabular}{|c|c|c|c|c|}
\hline \multicolumn{2}{|c|}{$\begin{array}{c}\text { Faktor-faktor } \\
\text { Strategi Internal } \\
\text { Kelemahan } \\
\text { (Weaknesses) }\end{array}$} & \multirow{2}{*}{$\begin{array}{l}\text { Bobot } \\
0,041\end{array}$} & \multirow{2}{*}{$\begin{array}{l}\text { Rating } \\
1,714\end{array}$} & \multirow{2}{*}{$\begin{array}{l}\text { Skor } \\
0,070 \\
\end{array}$} \\
\hline W1 & $\begin{array}{l}\text { Tidak ada } \\
\text { modal }\end{array}$ & & & \\
\hline W2 & $\begin{array}{l}\text { Peralatan masih } \\
\text { sederhana dan } \\
\text { tradisional }\end{array}$ & 0,049 & 1,571 & 0,076 \\
\hline W3 & $\begin{array}{l}\text { Proses produksi } \\
\text { secara manual }\end{array}$ & 0,045 & 1,428 & 0,064 \\
\hline W4 & $\begin{array}{l}\text { Kapasitas } \\
\text { produksi } \\
\text { rendah dan } \\
\text { hasil produksi } \\
\text { tidak tentu }\end{array}$ & 0,041 & 1,571 & 0,064 \\
\hline W5 & $\begin{array}{l}\text { Tidak ada } \\
\text { promosi }\end{array}$ & 0,023 & 2,571 & 0,059 \\
\hline W6 & $\begin{array}{l}\text { Lingkup } \\
\text { Pemasaran } \\
\text { Sempit }\end{array}$ & 0,045 & 1,571 & 0,070 \\
\hline W7 & $\begin{array}{l}\text { Kurangnya } \\
\text { keahlian dalam } \\
\text { manajemen } \\
\text { usaha }\end{array}$ & 0,030 & 2,000 & 0,06 \\
\hline W8 & $\begin{array}{l}\text { Pelaku usaha } \\
\text { kurang } \\
\text { memikirkan } \\
\text { tujuan jangka } \\
\text { panjang }\end{array}$ & 0,036 & 1,571 & 0,056 \\
\hline W9 & $\begin{array}{l}\text { Rendahnya } \\
\text { pendidikan } \\
\text { pelaku usaha }\end{array}$ & 0,041 & 2,428 & 0,099 \\
\hline Total & & 0,351 & 16,425 & 0,618 \\
\hline
\end{tabular}

Pada tabel tersebut diatas jumlah total nilai yang diperoleh dari perhitungan matriks IFE adalah senilai $(2,858)$, posisi nilai tersebut berada diatas atau melebihi nilai rata-rata tertimbang yaitu sebesar $(2,5)$. Posisi tersebut menunjukkan bahwa, secara internal industri kecil gula Aren di Desa Tongo saat ini cukup baik dalam memanfaatkan faktor kekuatan-kekuatan dan berupaya untuk mengatasi kelemahan-kelemahan yang ada.Adapun faktor kekuatan utama yang harus dipertahankan adalah produk gula Aren yang mempunyai keunikan dan kekhasan daripada produk lainnya adalah senilai $(0,263)$.

Faktor kelemahan yang dianggap memberikan pengaruh kepada pengembangan industri kecil gula Aren di DesaTongo dimulai dari rendahnya pendidikan pelaku usaha $(0,099)$, dan faktor kelemahan yang terakhir adalah pelaku usaha kurang memikirkan tujuan jangka panjang $(0,056)$.

\section{Matriks Faktor Strategi Eksternal (Peluang dan Ancaman)}

Berdasarkan penilaian yang sudah dilakukan oleh para informan terhadap variabel atau faktor-faktor strategis lingkungan eksternal industri gula Aren ini, didapatkan tabel hasil perhitungan yang ditampikan dan dijelaskan sebagai berikut:

Tabel 4. 3. Matrik Faktor Strategi

\section{Eksternal (EFAS)}

\begin{tabular}{|c|l|l|l|l|}
\hline \multicolumn{2}{|c|}{$\begin{array}{c}\text { Faktor-faktor } \\
\text { Strategi Eksternal } \\
\text { Peluang } \\
\text { (Opportunities) }\end{array}$} & bobot & Rating & Skor \\
\hline O1 & $\begin{array}{l}\text { Perhatian dan } \\
\text { dukungan dari } \\
\text { Pemerintah }\end{array}$ & 0,096 & 3,714 & 0,356 \\
\hline O2 & $\begin{array}{l}\text { Adanya event dan } \\
\text { pameran lokal }\end{array}$ & 0,074 & 3,571 & 0,264 \\
\hline O3 & $\begin{array}{l}\text { Jaringan internet } \\
\text { dan } \\
\text { telekomunikasi } \\
\text { yang semakin luas }\end{array}$ & 0,101 & 3,571 & 0,360 \\
\hline O4 & $\begin{array}{l}\text { Nilai tambah dan } \\
\text { potensi } \\
\text { pengembagan } \\
\text { produk gula Aren }\end{array}$ & 0,122 & 3,428 & 0,418 \\
\hline O5 & $\begin{array}{l}\text { Dukungan sektor } \\
\text { pariwisata }\end{array}$ & 0,096 & 3,857 & 0,370 \\
\hline \multicolumn{2}{|c|}{ Total } & 0,585 & & 1,768 \\
\hline
\end{tabular}




\begin{tabular}{|c|c|c|c|c|}
\hline \multicolumn{2}{|c|}{ Ancaman (Threats) } & Bobot & Rating & Skor \\
\hline $\mathrm{T} 1$ & $\begin{array}{ll}\text { Keadaan } & \text { iklim } \\
\text { atau cuaca } & \text { yang } \\
\text { buruk } & \\
\end{array}$ & 0,085 & 3,000 & 0,255 \\
\hline $\mathrm{T} 2$ & $\begin{array}{l}\text { Pohon sulit } \\
\text { dibudidayakan }\end{array}$ & 0,112 & 1,428 & 0,159 \\
\hline $\mathrm{T} 3$ & $\begin{array}{lr}\text { Bantuan } & \text { dari } \\
\text { pemerintah } & \text { tidak } \\
\text { merata } & \\
\end{array}$ & 0,080 & 1,285 & 0,102 \\
\hline $\mathrm{T} 4$ & $\begin{array}{l}\text { Rendahnya minat } \\
\text { generasi penerus }\end{array}$ & 0,085 & 2,000 & 0,170 \\
\hline T5 & $\begin{array}{l}\text { Keterbatasan } \\
\text { pengetahuan } \\
\text { teknologi }\end{array}$ & 0,069 & 1,714 & 0,118 \\
\hline T6 & $\begin{array}{lr}\text { Adanya produk } \\
\text { campuran } \\
\text { Aren }\end{array}$ & 0,096 & 2,428 & 0,233 \\
\hline & Total & 0,527 & & 1,037 \\
\hline
\end{tabular}

: $\mathbf{0 , 7 3 1}$

Skor Total Kekuatan dikurangi Kelemahan

Pada tabel 4.3 jumlah total nilai yang diperoleh dari matriks EFAS adalah senilai $(2,805)$, posisi nilai tersebut berada diatas nilai rata-rata tertimbang yaitu sebesar $(2,5)$. Posisi tersebut menunjukkan bahwa secara eskternal, industri kecil gula Aren di Desa Tongo saat ini cukup baik dalam memanfaatkan faktor kekuatankekuatan dan berupaya untuk mengatasi ancamanancaman yang ada.

Dari penilaian tersebut, didapatkan bahwa faktor-faktor peluang pada kegiatan industri kecil gula Aren di Desa Tongo yang seharusnya dapat dimanfaatkan oleh para pengrajin antara lain, adanya nilai tambah dan potensi pengembagan produk gula Aren menjadi gula semut yaitu $(0,418)$. Faktor yang terakhir adanya event dan pameran lokal yang diadakan oleh instansi pemerintah maupun swasta untuk penjualan gula Aren, gula semut $(0,264)$.

Faktor-faktor yang menjadi ancaman bagi industri kecil gula Aren di Desa Tongo yang seharusnya mampu diantisipasi dan dihindari agar industri ini dapat terus berlangsung dan tidak terjadi kendala dalam realisasi strategi pengembangannya yang paling tinggi yaitu Keadaan iklim atau cuaca yang buruk $(0,255)$ dan ancaman yang terakhir adalah bantuan dari pemerintah tidak merata atau belum dirasakan semua oleh pengrajin industri gula Aren ini $(0,102)$.
Berdasarkan hasil perhitungan pada analsis pada tabel diatasdapat dilihat bahwa saat ini posisi relatif industri kecil gula aren menunjukkan situasi yang sangat menguntungkan. Dimana industri kecil gula Aren di Desa tongo ini memiliki kekuatan yang dapat dipertahankan atau ditingkatkan, serta memiliki peluang yang bisa dimanfaatkan dengan baik dan semaksimal mungkin. Dengan demikian, strategi pengembangan yang sebaiknya digunakan oleh industri kecil gula Aren di Desa Tongo adalah strategi yang mendukung pertumbuhan agresif atau (Growth Oriented Strategy) dalam hal ini alternatif strategi yang sesuai adalah strategi S-O (Strength-Oppourtunities) yaitu dengan memanfaatkan kekuatan yang dimiliki industri untuk meraih peluang yang ada, diantaranya: (1) Mengoptimalkan keahlian dan keterampilan para pengrajin untuk berkomitmen menjalankan inovasi produk gula Aren menjadi gula semut . (2) Menjadikan gula Aren sebagai OVOP (One Village One Product), dan (3) Mengoptimalkan dukungan pemerintah dalam melakukan pengenalan produk gula Aren dan pengembangan produknya (gula semut) melalui even dan pameran lokal atau nasional.

Selain memamfaatkan kekuatan di atas untuk mengembangkan produksi gula aren di perlukan inovasi atau modernisasi diantaranya :

1) Rekayasa proses produksi

Proses produksi gula aren mengalami beberapa kendala yaitu apabila nira tidak langsung di masak akan mengakibatkan penurunan $\mathrm{PH}$ dan nilai brix sehingga gula aren tidak bisa memadat (gait).Rekayasa dalam proses produksi dengan menambahkan ekstrak tanaman yang memiliki fungsi sebagai pencegah "gait"sangat memungkinkan untuk meningkatkan nilai faktor konversi produk menjadi lebih tinggi, sehingga berdampak pada peningkatan nilai output serta lebih meningkatkan nilai efisiensi dari suatu produk.

2) Perancangan desain kemasan gula aren

Dalam sebuah perancangan akan di buat kemasan yang sesuai dengan jenis produknya sehingga produk yang sebelumnya kurang di kenali dapat hadir dengan tampilan yang menarik pembeli. Kemasan akan di rancang dengan mengutamakan sisi kepraktisan, ekonomis, higienis, serta tidak memberatkan produsen dari segi produksi serta konsumen dari segi harga. 


\section{PENUTUP}

\section{Kesimpulan}

Berdasarkan hasil analisis data pada Industri pembuatan gula aren di Desa Tongo Kecamatan Sekongkang, Kabupaten Sumbawa Barat, maka diperoleh faktor-faktor lingkungan internal dan eskternal, antara lain:

1.Lingkungan internal yang memberikan kekuatan dalam perkembangan industri kreatif sektor kerajinan terdiri dari: Produk yang unggul, keahlian dan keterampilan yang sangat matang, SDM anggota keluarga sendiri, bahan baku mudah didapatkan, produk yang unik dan khas, produk banyak manfaat, adanya inovasi dan pengembangan produk

2. Lingkungan internal yang memberikan kelemahan dalam perkembangan industri kreatif sektor kerajinan terdiri dari: Tidak ada modal, peralatan masih sederhana dan tradisional dan Proses produksi secara manual, kapasitas produksi rendah dan hasil produksi tidak tentu, tidak ada promosi, lingkup pemasaran sempit, kurangnya keahlian dalam manajemen usaha, pelaku usaha kurang memikirkan tujuan jangka panjang, rendahnya pendidikan pelaku usaha

3. Lingkungan ekternal yang memberikan peluang bagi perkembangan industri kreatif sektor kerajinan terdiri dari: Perhatian dan dukungan Pemerintah, adanya event dan pameran lokal, jaringan internet dan telekomunikasi yang semakin luas, nilai tambah dan potensi pengembagan produk gula aren, dan dukungan sektor pariwisata

4. Lingkungan ekternal yang memberikan ancaman bagi perkembangan industri kreatif sektor kerajinan terdiri dari: Keadaan iklim atau cuaca yang buruk, pohon sulit dibudidayakan, bantuan dari pemerintah tidak merata, rendahnya minat generasi penerus, keterbatasan pengetahuan teknologi

Berdasarkan hasil analisis lingkungan internal dan eksternal terkait strategi pengembangan pada Industri pembuatan gula Aren di Desa Tongo berada pada posisi yang sangat menguntungkan. Dimana industri kecil gula Aren di Desa Tongo Kecamatan Sekongkang ini memiliki kekuatan yang dapat dipertahankan atau ditingkatkan, serta memiliki peluang yang bisa dimanfaatkan dengan baik dan semaksimal mungkin. Dengan demikian, strategi pengembangan yang sebaiknya digunakan adalah strategi yang mendukung pertumbuhan agresif yaitu strategi S-O (Strength-Oppourtunities) yaitu dengan memanfaatkan kekuatan yang dimiliki industri untuk meraih peluang yang ada, diantaranya: (1) Mengoptimalkan keahlian dan keterampilan para pengrajin untuk berkomitmen menjalankan inovasi produk gula Aren menjadi gula semut. (2) Menjadikan gula Aren sebagai OVOP (One Village One Product). Dan (3) Mengoptimalkan dukungan pemerintah dalam melakukan pengenalan produk gula Aren dan pengembangan produknya (gula semut) melalui even dan pameran lokal atau nasional.

\section{REFERENSI}

Anonim, 2010. Pengembangan Cara Pengolahan Nira Aren Menjadi Gula. Balai Penelitian dan Pengembangan Industri.Badan Penelitian dan Pengembangan Industri.Departemen Perindustrian Manado.

Apandi Y, 2008. Aren Tanaman Pemanis Alami. PT.Intimedia ciptanusantara. Jakarta.

Arikunto, S. 2000. Prosedur Penelitian suatu Pendekatan Praktek. Rineka Cipta. Jakarta.

Arsyad, Soeratno, 1999. Metodologi Penelitian. UPP AMP YKPN.Jogjakarta .

Badan Penelitian dan Pengembangan Pertanian. 2002. Pemahaman Pedesaan Secara Partisipatif Menunjang Kegiatan Usaha Tani Terpadu (Panduan Teknis). Badan Penelitian dan Pengembangan Pertanian. Departemen Pertanian. Jakarta.

Baharudin. 2007. Pemanfaatan nira aren (arengapinnata mers) sebagai bahan pembuatan gula putih kristal. Junal Perennial. 3(2) : 40 - 43. Fakultas Kehutanan Universitas Hasanuddin.

Balai Penelitian Tanaman Palma. 2010. Deskripsi produk dan Teknologi Pengolahan Kelapa Parut Kering.Balai Litbang Pertanian. Indonesia.

Bambang Supomo dan Nur Indriantoro, 2002. Metodologi Penelitian Bisnis, Cetakan Kedua, Yogyakara; Penerbit BFEE UGM

Budiman, A., Assyaukanie, L. \& Stanley, 1959-. (2006). Kebebasan, negara, pembangunan: kumpulan tulisan, 1965-2005. Kerja sama Freedom Institute dan Pustaka Alvabet.

Evalia NA. Syahyana R, Nofialdi. 2014. Strategi Penguatan Agroindustri dan Nilai Tambah Aren di Kecamatan Lareh Sago Halaban.di Dalam: Seminar Nasional Pertanian. Fakultas Pertanian.Universitas Andalas di Padang

Feryanto, 2010. Peranan Agribisnis Dalam Pembangunan Pertanian dan Ekonomi. 
Irawan dan Suparmoko, M. 1992.Ekonomi Pembangunan Edisi Pertama. BPFE

Yogyakarta: Yogyakarta

Kristianingrum, S. 2009. Analisis Nutrisi Dalam Gula Semut. Fakultas Matematika dan Ilmu Pengetahuan Alam Universitas Negeri Yogyakarta.Yogyakarta.

Mustaufik dan Karseno. 2004. Penerapan Dan Pengembangan Teknologi Produksi Gula kelapa kristal Berstandar Mutu SNI untuk Meningkatkan Pendapatan Pengrajin Gula Kelapa di Kabupaten Banyumas. Laporan Pengabdian Masyarakat. Program Pengembangan Teknologi Tepat Guna. Jurusan Teknologi Pertanian Unsoed, Purwokerto.

Ningtyas. 2012. Analisis komparatif usaha pembuatan gula merah dan gula semut di kabupaten Kulon Progo. Program Studi Agribisnis Fakultas Pertanian Universitas Sebelas Maret Surakarta.

Punaji Setyosari. 2012. Metode Penelitian Pendidikan dan Pengembangan. Prenada Media. Jakarta.

Rangkuti, F, 2009. Analisis SWOT Teknik Membedah Kasus Bisnis, Reorientasi, Konsep, Perencanaan strategis untuk Menghadapi abad 21. Cetakan 16.PT. Gramedia Pustaka Utama. Jakarta.

R. David, Fred. 2011. Strategic Management (Manajemen Strategis - Konsep, Buku 1 edisi 12). Jakarta: Salemba Empat.

Sugiyono. 2010.Metode Penelitian Kuantitatif Kualitatif \& RND. Bandung: Alfabeta. 